\title{
4. Public stories and new networks Donor-conceived activism
}

From the very beginning of my research, I was particularly interested in how the donor-conceived themselves intervene and participate in transformative processes by becoming politically active. A closer look at the literature reveals that donorconceived activism is actually not a new phenomenon: according to the Warnock Report, an organisation called Donors' Offspring had submitted evidence to the Warnock Committee (1984: 96). Donors' Offspring was founded in 1981 by Candace Turner, a donor-conceived person from the US (Turner 1993), making it the earliest example of donor-conceived activism that I could find in the literature. ${ }^{1}$ Turner described the group as "an educational and support organization for those connected with high tech conception" (1993: 197). She had apparently also developed a register "for exchanging information between genetic donors and their offspring" (ibid.). ${ }^{2}$ None of my interviewees mentioned Turner or Donors' Offspring, and the group seems to have no online presence, although an address with a P.O. Box can be found online. ${ }^{3}$ However, for the groups active today, to which many of my interviewees belonged, the Internet was of central importance. These groups provide opportunities to exchange information and compare experiences. At the same time, they offer a way to cope with the (offline) experience of not being understood by others, as people who have a similar story gather together in a safe virtual place.

Apart from this community-building function of stories, they were told not only in protected online spaces but also in public. These publicly shared narratives are powerful and culturally legible, as authenticity and thus authority is attributed to them. In turn, they can stimulate the production of more narratives. But in order for this process not to be suspended, new narratives must be produced again and

2 Haimes also mentions that Turner "provides a model bedtime story, to assist parents in telling a four-year-old child of his/her conception and suggests developments in the story as the child gets older" (1998: 66). She lists a publication that is entitled "A baby creation story" and authored by Turner as one of her references (1998: 75). www.donorchildren.com/resources (last accessed May 23, 2021). 
again. I suggest that donor-conceived activism can be interpreted as an example of a recursive public; a term coined by anthropologist Christopher Kelty (2008) in his ethnographic study of free software. He defines a "recursive public" as follows: "A recursive public is a public that is constituted by a shared concern for maintaining the means of association through which they come together as a public." (2008: 28) It is "a public that is vitally concerned with the material and practical maintenance and modification of the technical, legal, practical, and conceptual means of its own existence as a public" (2008: 3, emphasis in original; see also Nayar 2012 for an exploration of the making of recursive publics through narratives). Online-based communities play a central role in the production and dissemination of new narratives, and thus in the maintenance of the recursive public. However, the step into the media public sphere can be motivated differently. In the first two sections of this chapter I will examine two different motivations that are linked to different attitudes towards donor conception. In doing so, I will also address the question of what, in the eyes of my donor-conceived interviewees, constituted a "real" or "good" family. I will then go into more detail about the Internet communities in which donorconceived people connect with others who also have a story to tell. In the last part of the chapter, I will discuss an organisation that is particularly important and significant for my research, and that contributes significantly to the maintenance of a recursive donor-conceived public in Germany.

\subsection{Seeing the truth, telling the truth: The fight for real families}

A "hetero-bionormative" view of the nature of family, which Leighton (2013:54) sees as the core of "right to know" arguments against anonymous donation (section 3.4), was neither the only nor the most common view among the donor-conceived persons I met. However, such views were expressed by at least some of my interviewees. They were very critical of gamete donation per se, arguing that the use of donated gametes - regardless of whether the donor was anonymous or not - always damages family life and "identity formation". Although their views might be unusual, they were not exceptional. Nevertheless, it should be noted that the space I am giving to this analysis is not proportional to the number of people who held such opinions. As with other stories that I tell, evaluating them in terms of general representativity is not my aim. In view of the fact that there is no reliable information on how many donor-conceived persons there are in total (see section 7.2), this would arguably be an impossible task. Since I try to reflect the diversity in my field of research by including many different opinions rather than excluding those that seem rather unusual, I will discuss these more unusual views in more detail in this section, focusing mostly on the point of view of one particular person. 
Those who saw donor conception as a dangerous interference with the natural order and structure of the family spoke very clearly and openly about their views at the public and political level, as they usually wanted to eliminate gamete donation, whether anonymous or not. This was especially the case for those of my British interlocutors who publicly opposed donor conception. They were involved in court cases, government consultations and campaigns, and told their stories to journalists and other researchers. Elizabeth Chapman from the UK was one of the harshest critics of donor conception that I met during my research. Since discovering more than two decades ago at the age of 40 that she had been conceived with donor sperm, she had been on a mission to raise public awareness of what she described as the overlooked dangers of gamete donation. She considered donor conception to be a human rights violation, as it prevented children from growing up with their "real parents". Elizabeth, who lived an otherwise quiet life with her now retired husband in a picturesque little town, laughed and commented that she was, in a way, two persons, as "there was the Elizabeth that just was the wife and mother, and then there's Elizabeth the donor-conceived offspring".

The interview I conducted with Elizabeth took place the week after the PET event on birth certificates (section 3.6). When her husband Andrew came to us during our conversation with water and coffee, he mentioned that a Facebook group for donor-conceived persons in which they were both active, was "going mental", as members were discussing the impeding Law Reform, the programme of which had not yet been announced. ${ }^{4}$ They all hoped that it would include a project on birth registration. Elizabeth herself mentioned her birth certificate before I could ask my very first question. Immediately after we settled in her living room, she began talking about her birth certificate in an agitated voice, angrily stressing that the document was a lie. She then jumped to her feet, hurried into the next room, and came back with a tin that contained not only her family's birth certificates but also her marriage certificate. She showed me her documents and pointed out that her late stepfather was registered as her father on her marriage certificate. On her birth certificate, however, the name of her mother's first husband, who had already died in her childhood, was registered. He was the one she had thought was her father and whose surname she had carried before her mother remarried. Since the names of the men registered as her father did not match, Elizabeth commented laughingly that she had already wondered whether her marriage to her husband was invalid.

However, this was not the reason why these documents bothered her. Instead, she was angry because she wanted a document that would reflect the truth about mentioned seemed to be open to close 'allies' of the donor-conceived. It is also possible that the two had a joint Facebook account. 
her genetic origins. The way Elizabeth showed me her certificates is reminiscent of the adoptees in Carsten's study, who often referred to or even produced "mnemonic objects" (2000b: 692), such as personal letters and baby clothes, when being interviewed. Carsten argues that such "objects are often vivid and painful reminders of the missing threads of continuity between them" (2000b: 696). Like the adoptees in Carsten's study, who attached great importance to their own families and marriages, Elizabeth seemed very concerned about her "own connections in the present and future" (ibid.), which was reflected in the presence of framed family photographs throughout the entire ground floor. Her relationship with her children and grandchildren was close, and the "dense network of kin relations" (2000b: 688) that struck Carsten about her interlocutors seemed to characterise the lives of Elizabeth and her husband as well. The two had already known each other in adolescence, had been married for over 40 years, and were still connected by a noticeably affectionate relationship. While their own family life was marked by continuity and closeness, her birth certificate and its production in the interview served to show and prove the discontinuity caused by donor conception.

Appearing in the media with her story and her views was something she felt obliged to do, as she was firmly convinced that "people who can see the truth must tell the truth". Shortly after she learnt that she was donor-conceived, she contacted a major British daily newspaper: "I thought, "This is wrong. People need to know about this." The editors had then reached out to her, and an article about her appeared shortly afterwards. In addition to speaking to journalists, Elizabeth had also participated in government consultations. Her lobbying work was not limited to the UK but also extended to an international level, and she had made several written statements for consultations in other countries. Speaking about the overlooked dangers of donor conception, Elizabeth pointed out that "people who've been adopted very often end up in prison, they're far more likely to be in prison than an ordinary member of the public. So, is there a higher proportion of us who have ended up on the wrong side of the law?" She then argued that this question was impossible to answer since most donor-conceived persons did not know how they had been conceived. Another UK critic of donor conception expressed a similar opinion and commented that researchers should investigate whether a large number of people conceived with donated sperm would end up in prison because of their identity problems.

While it was common for people to argue that "children need to know where they come from" to be happy and healthy, it was less common for people to argue that the donor-conceived were more susceptible to becoming criminal than the 'regular' citizen. Beliefs that donor-conceived persons are particularly susceptible to crime were rare and represented a more unusual form of criticism. However, I would argue that they are in fact based on an assumption held by the majority of the people that I interviewed: that a stable and healthy identity can only be developed if 
children are given knowledge about their origins, with strict opponents of DI arguing that children must also grow up with their genetic and "real" parents. Moreover, I would argue that a moral and medical discourse on reproductive technologies that portrays those pursuing parenthood with the help of these technologies, as well as those offering them as selfish and immoral actors, also has the tendency to create a subcategory of children that are seen as inherently defect, and potentially even delinquent. Since donor conception is seen as inherently faulty, these children are seen as being outside of the community of proper citizens. The 'crime critique' in particular ties in with some of the findings of Korolczuk (2016), who has explored the ways in which reproductive technologies are ascribed a debilitating potential in public debates on reproductive technologies in Poland. Korolczuk shows how those opposing reproductive technologies oftentimes propagate the view that children conceived via IVF are more prone to physical and psychological impairments (2016: 131). She points out that "undermining the physical and mental health of children conceived with the use of reproductive technologies demonstrates that it is not only moral or religious values but national identity that is at stake" (ibid.). Referring to the stigmatisation of 'IVF children' in Poland, she argues that they "fall into the category of citizens, whose value is contested because of the alleged risks associated with their bodies" (ibid.).

What is of course striking and somewhat bewildering in the case of donorconceived persons rejecting reproductive technologies and specifically donor conception is that they, at least indirectly, envisaged themselves as a threat to the community of those who were normal, healthy, and 'naturally' conceived, although all of them appeared to be law-abiding citizens. It was almost as if they saw themselves as a painful reminder that donor conception, which they perceived as an abomination, was still being practiced. For example, another activist from the UK commented that both donor conception and being donor-conceived were horrible. I could not help but thinking that he wished he did not exist, even though he seemed to live a life that, especially given his professional success, I would have assumed to be fulfilling. In contrast, others argued that because they themselves had been conceived via sperm donation, and were happy to be alive, they did not (and could not) reject the practice per se. Still others seemed to be bothered by such opinions, arguing that one did not have to approve of the circumstances of one's conception in order to live a happy life, while those who, like Elizabeth, held these more unusual opinions would argue that it was being donor-conceived that prevented them from being happy in the first place.

At four hours, the interview with Elizabeth was one of the longest I conducted. Even though she had often spoken about her views, she seemed no less passionate about them. Towards the end of our conversation, I asked Elizabeth where she saw her own role in the discussion about donor conception in the future. She answered that she would "still do what I can now and again, but it has been a long time". 
Elizabeth added that she would be more likely to stay "behind the scenes" and encourage the next generation of donor-conceived persons, with whom she was in contact through various Facebook groups, to get involved. She felt that "it's nice to be pro-active rather than to feel like a victim" and that "when you're actually doing things, you feel less of a victim". Although she stressed the active "doing" of things, and attributed a positive effect to it, she had at the same time a pessimistic opinion about the legal situation and its future development. She feared in particular that changing the law to allow same-sex couples to marry had been at the expense of the donor-conceived:

Elizabeth Chapman: "So there has to be donor conception and there has to be surrogacy to nourish their [same-sex couples'] right to have children. Our rights now have to be suppressed again. The rights of the donor-conceived have to be suppressed in order to fulfil the wishes of the adults. And I don't think there will be any more changes in legislation."

Elizabeth and others who opposed donor conception altogether and were publicly and politically active did not explicitly condemn gay and lesbian people for their sexuality. However, it was clear that many of them believed that a child should only be conceived in a heterosexual relationship. Donor-conceived activists also frequently voice such opinions on an international level. They repeatedly point out publicly that children with lesbian parents, or born to a single mother by choice, suffer from the absence of a father figure. An example of this is the Australian activist Millie Fontana. Fontana was conceived through sperm donation, grew up with two mothers, and is publicly very critical of same-sex parenting. She mentioned in an online article that "there is not a moment where I have looked back and thought that I did not crave that male stability and that father in my life" (Fontana 2017). If families with heterosexual parents are seen as the only valid family form, then homosexual and other couples, as well as singles, are automatically seen as unsuitable parents who cannot belong to the group of "real" families. However, one should keep in mind that "[i]t is but a short step from positioning lesbians and gay men somewhere beyond "the family" - unencumbered by relations of kinship, responsibility, or affection - to portraying them as a menace to family and society", as Weston (1991: 23) points out. Following Weston, I would argue that even if people claim that they have no reservations about homosexuality 'per se', but only about gay and lesbian couples forming families through marriage and donor conception, such an opinion might lead to non-heterosexual couples being viewed as a threat to family life.

Weston's work with gay and lesbian families who emphasise the importance of spending time together for the creation of permanent family bonds, and who have oftentimes been rejected by their families of origin because of their sexuality, is also important for showing that "blood is not intrinsically thicker than water" (1991: 24). 
This proverb in particular was invoked by several of the opponents of donor conception that I interviewed. Elizabeth used a similar expression, stating that she had been connected to her donor by an "invisible umbilical cord". For those who stressed the importance of growing up with one's "real" family, genetic and biological connection equals permanence. Weston's work offers a different perspective on the relationship between genetics, biology and permanence. It is "the possibility of being rejected by blood relatives for a lesbian or gay identity" (1991: 135) that shaped the meaning the people in her study attached to "family", with rejection "undermining the permanence culturally attributed to blood ties while highlighting categories of choice and love" (ibid.). She points out elsewhere that biology is not inherently permanent: "In and of itself, nothing about "biological" connection implies permanence, much less ongoing relationship or solidarity." (1995: 103) Weston argues that given the way in which cellular tissue is constantly renewed, "biological processes might just as easily constitute a signifier of change and flux rather than continuity and control" (ibid.). In comparison to what I was told in the UK, the criticism voiced by German activists often seemed more moderate. I suggest that this has to do with some of the politically active protagonists. For example, Spenderkinder was co-founded by a lawyer who seems to have established a certain line of argumentation - (past) anonymity as a violation of the law - among the members. The arguments, as far as the right to know is concerned, seemed to be more 'sober' and less emotional than the ones voiced by British activists. Nevertheless, I will point out in the last part of this chapter that argumentation and criticism based on the alleged permanence of biological connections was not absent from the German discourse either (section 4.4).

\section{2 "Just one of many ways": Taking a stand for normality}

Not everyone I met in the UK or Germany rejected all forms of gamete donation, and even those who were critical or sceptical of conventional and commercial gamete donation did not necessarily agree that "real and good families must be genetically related" (Leighton 2013: 54). Instead, "good families" were usually defined as those whose members were open with each other. A few people had even taken on a kind of ambassadorial role. They wanted to convey to the public that donor conception was a normal way of creating a family. I will discuss the motivations and views of two people for whom this was the case in the following section. The examples I have chosen are rather unusual cases in some ways: the first person became a sperm donor himself, and the second person decided to get in touch with a journalist very early on precisely because she was not, unlike Elizabeth Chapman, hurt by finding out she was donor-conceived. It was more common for people to be ready for an interview only after a few months or years. Nevertheless, the way the 
two donor-conceived persons portrayed in this section viewed openness as being vital for the donor-conceived and their families was in fact typical for the way "seethrough kinship" (Edwards 2018) was idealised by the people I interviewed.

The extent to which openness was seen as the hallmark of a "good" family was particularly evident in the story of David Winkler, who was conceived in the former German Democratic Republic (GDR) in the early 1980s. Shortly before I met him, he had already been interviewed by a journalist for an upcoming article. In contrast to those who strictly rejected donor conception and went public to alert others to the dangers of the practice, David was pursuing a different goal with his media activities. He was concerned with publicly advocating the normalisation of reproductive medicine and non-traditional families. David was critical not only of anonymous donations but also of conventional "identity release" donors. In his opinion, it was essential for the healthy development of a child to know the identity of the donor and to get to know him personally, if desired, instead of having to wait until a certain age. This had shaped his own life in a special way. Shortly after he learnt of the circumstances of his conception, two of his closest friends, who were a lesbian couple, told him that they were planning on having a child. They mentioned that they were currently going through online catalogues of sperm banks to find a suitable donor. He then told them his story and shared with them his concerns about anonymous donors. Through the discussions they had afterwards, they came to the decision that David should be the sperm donor. The three friends had agreed that the child, who had not yet been born or conceived at the time of the interview, should grow up with the two women. Nevertheless, it was planned that David should always be a part of the child's life and should also be recorded on the birth certificate. The trio had discussed their plans for a long time and believed, according to David, that "nothing can go wrong because there are no gaps" if everyone was as transparent and open as possible. While David's insistence that children must know their donors could be seen as a confirmation of heteronormative assumptions about parenthood, "multiple parents question the centrality of the nuclear family" (Ryan-Flood 2005: 201).

David himself emphasised that he wanted to show through his life and his media activities that the type of family constellation in which a child grows up is irrelevant to the child's well-being as long as there are people who care for him or her. In the first article for which he had been interviewed, his real name would not appear. Since David's brother, who was also donor-conceived, did not yet know about the circumstances of his conception, David had asked to only be mentioned with a pseudonym. However, he hoped to be able to deal with the issue completely openly once all his intra-family issues had been sorted out. His reluctance to be pseudonymised in the article seemed to be symptomatic of his desire for openness and honesty. Not only did he want to deal openly with his own story, but also with the topic of donor conception in general. David therefore did not want to com- 
ply with his parents' wish to keep the circumstances of his conception completely secret:

David Winkler: "Because I don't want to be part of such a lie or deception [...] these are not my fundamental beliefs and principles [Lebensüberzeugungen und Maximen], and I would continue to act as if we, the children, are some kind of flaw or taboo. And that's stupid, that doesn't feel good. And I don't think it makes much sense for society as a whole to continue to taboo it, you should simply open it up and normalise it completely. That's just one of many ways to have children."

While DI with a non-anonymous donor in particular was often considered a completely acceptable practice by my interviewees and, as David put it, "one of many ways to have children", other measures were often rejected because they were seen as too much of an intervention in the natural order of things. As with couples who undergo fertility treatment and refer to the naturalness of the method they have chosen (Knecht et al. 2011: 40-41), my interviewees often drew a line between what they saw as natural and unnatural, thereby normalising the circumstances of their own conception. They mentioned particularly frequently that they were critical of surrogacy, without me ever bringing it up. Often, the women I interviewed brought up their own pregnancies and claimed that they knew that pregnancy created a special bond between mother and foetus, arguing that the separation from the surrogate harmed the child. Interestingly, even Diana Kraft, whom I will introduce shortly and who was very positive about donor conception, drew a line between what she considered natural and normal and what she felt went "way too far". While Diana believed that sperm donation led to the birth of a normal human being, she saw surrogacy as something that was inherently dangerous. She raised this issue when I asked her whether she believed that the state or clinics should take responsibility for donor-conceived children learning about the circumstances of their conception. She explained that in her opinion, parents definitely had the greatest responsibility. Diana believed that clinics should ensure a careful donor selection process. In her opinion, the state should have the task of making sure that reasonable legal regulations existed. In particular, she felt that surrogacy should remain prohibited in Germany since "these nine months in a woman's belly, they just don't pass by without leaving a trace".

Apart from advocating for the normalisation of donor conception, David also wanted to 'put himself out there' to heighten his chances of finding donor siblings. For others, the idea of attracting the attention of donor siblings, and perhaps even the donor, was more of a desirable side effect of speaking to journalists. Especially those who appeared on TV hoped that they would be seen and contacted by donor siblings or even past donors. David, on the other hand, connected his public work more directly with the idea of finding donor siblings. He was convinced that most people had no idea how they had been conceived, and he suspected that even many 
of those who knew and wanted to know more had not heard about genetic testing. David had found out that the doctor who had treated his mother was responsible for the conception of about 600 children, and he believed that talking to journalists was the only way to find his donor siblings who might be among those 600 . He hoped that articles and reports might have the potential to reach parents and make them aware of the importance of telling their children, and that more people would take a DNA test once they were told about their origins: the more people knew they were donor-conceived and did a DNA test, the higher the chances of having a match. While others tended to hope that their own donor siblings or donor would contact them if they were seen in the media, David seemed to hope to increase the chances of all donor-conceived persons to find their relatives (see also section 8.4 for a discussion of his approach to "waiting for DNA/genetic matches").

A strong desire to promote the social acceptance of donor conception was the main reason why Diana Kraft agreed to an interview for a German TV station just four weeks after she learnt of the circumstances of her conception. She was working in $\mathrm{PR}$, and I got the impression that her job as a press spokesperson was probably the perfect kind of work for her: Diana seemed to be a very outgoing, open person who likes to talk to people. When she told me that we would only have an hour for the interview, as she had not been able to take the day off, I was initially worried that I might not be able to ask her everything I had written down. However, not only did she speak very quickly, but she also seemed to have no problem putting her thoughts into words, a skill she had probably cultivated in her PR work. Before the interview she had sent me a link to the documentary for which she had been interviewed, which mostly focused on German couples travelling abroad for fertility treatments. Diana stressed, both in the interview as well as in the documentary, that nothing had changed in her relationship with her parents since she and her brother learnt that they were donor-conceived. She told me that "for our very personal situation", late disclosure had been the right thing, since she and her brother were "stable in the family of origin [Herkunftsfamilie] and in our own lives". Diana was aware that others did not feel this way and, despite her own experience, was in favour of telling children as early as possible, "so that it's just normal". Together with her brother, she had quickly decided to bring the topic to "a normal level" so that they could talk about it openly with their parents: "Because I'm not willing to somehow make a bigger deal out of it than it actually is." Finding out that she was donor-conceived had merely modified her story by introducing another "variant", which had not resulted in any changes in her family relationships.

Nevertheless, Diana had been immediately curious about her donor and her donor siblings. She therefore began searching online for information and immediately came across Spenderkinder. I asked her how she had ended up on TV, and she told me that soon after she contacted the organisation and signed up for their mailing list, a journalist's request was shared on the list. Since her mother telling 
her the truth had not led to a breakdown in their relationship, Diana felt that her story might encourage other parents to be open with their children, although she emphasised that she did not have the time to become an activist. Her decision to contact the journalist was also motivated by her belief in the importance of promoting tolerance:

Diana Kraft: "That's how it somehow came about, and I said to myself, the more this subject becomes public, the more normal it becomes, of course, so I'm trying very hard to take away this fear from people like my mother, that when they break this secret, everything is broken, it doesn't necessarily have to be like that. And you also have to stand up for an open and tolerant society, and if you use yourself as an example, hello, I'm an exotic too, but look, [laughs] I'm completely normal, then maybe every step, every little piece of the puzzle somehow makes people a bit more open-minded and not as narrow-minded and intolerant. I thought, maybe that makes sense, and then I said to myself, yes, that's actually a pretty good vehicle. And of course, perhaps a donor will get in touch. Or a half-brother and sister or whatever, when it gets aired. That didn't work, but [laughs] it was worth a try."

Both Diana and David made references in their stories to what they considered normal. For Diana, donor conception was something that results in normal children, and she had made it a normal topic of conversation with her brother. David emphasised that the treatment was "just one of many ways to have children" and a way to fulfil a deep desire for children, which he believed most people had. Such references to normality can help to create continuity in narratives (Polat 2018: 121). The fact that a donated gamete was involved in a person's conception is interpreted as something that has no particular significance, neither for the individual nor for the family, and about which one can therefore speak openly and without fear. Openness and trivialisation are also normalisation practices that couples who use reproductive technologies resort to (Knecht et al. 2011). While not everyone decided to appear in the media, the importance of being open and the dangerous nature of family secrets were topics that kept appearing constantly in interviews. Secrecy was described as being harmful and "toxic" not only for healthy personal development but also for the creation of close family relationships. The insistence on the importance of disclosure contains a strong "message of inadequacy: the inadequacy, that is, of parents who do not tell their children how they were conceived" (Edwards 2018: 166). Good parents are only those who tell and continue talking about it. 


\subsection{The stories of others: Finding information, validation and community online}

The majority of my interviewees only had little information about why their parents had decided on treatment with donated gametes, and why they had ended up at a specific clinic. Several people told me that their parents either refused to talk about the subject or that they themselves did not want to put their parents in unpleasant situations by asking questions. Those who knew a little more usually mentioned that their parents had been informed by doctors or nurses about the possibility of treatment with donor sperm and had also been referred to a particular clinic or physician. In other cases it seemed to have been more complicated. David Winkler had been told by his parents that they had only learnt "by detour and hearsay" about the few doctors who carried out DI in the former GDR back in the 1980 . They had managed to contact one of these physicians, who had then agreed to treat them. This is significantly different not only from the way in which patients inform themselves today but also from the way my interviewees themselves had found out more about donor conception and gamete donation. ${ }^{5}$ Those who had learnt since the mid-2000s that they were donor-conceived, or were only more interested in it since that time, usually first turned to the Internet, or more precisely to Google, to get a first overview. Several of my interlocutors told me that they had done so almost immediately after finding out. Their desire to learn more about donor conception was often linked to a general feeling of confusion or disbelief. Especially those conceived in the 1970s or early 1980 s usually commented that they had not even known that these treatment options had already existed back then, and they thus wanted to know more about DI in general. But even for them, the Internet was usually not only a way to get information but also a way to network with other people. The online-based communities that donor-conceived persons create and use to exchange and share information will be introduced in this section. I will discuss both what they meant to the people I interviewed and how they have changed over time. Finally, I will examine a special feature of many groups, namely their hidden and closed nature.

Online communities, and especially Facebook, had become an important part of Jennifer Bunton's life, and of how she made sense of donor conception. Jen-

$5 \quad$ Writing specifically about how those travelling abroad for treatment select their fertility clinic, Shenfield et al. note that in total, $41 \%$ of European patients had used the Internet as a source of information (2010: 1364). There were considerable differences between the seven countries that they studied. While only a quarter (25.3\%) of Italian patients would frequently use the Internet, and instead relied more heavily on their doctor's advice, almost three quarters of Swedish patients (73.6\%) as well the majority of those coming from Cermany $(65.0 \%)$ and the UK (58.5\%) would cite the Internet as a frequently used source of information (2010: 1366). 
nifer, who was in her mid-30s, had grown up in the UK and emigrated to Australia with her daughter several years ago. The interview with her was the only one I conducted via Skype. Jennifer, who had known about the circumstances of her conception since her childhood, only began to search for her donor a few months before I interviewed her. By her own admission, Jennifer had simply not been aware that there was anything she could do to find her donor. Instead, she had always accepted his anonymity silently until she came across an article about DNA testing on Facebook. Having always felt a very strong desire to find her "paternal family", she immediately began looking online for more information, and commented that she had "just googled the hell out of donor conception". Jennifer had joined not only the DCN, through which she had learnt of my research, but also the DCR and various Facebook groups. She explained that she had "found as many things as possible that I could be a part of or connect with" and that she had "just kind of tried to put myself out there". Prior to that, she had never even heard of anyone else who was donor-conceived. For her, joining groups had been about

Jennifer Bunton: "[...] hearing other people's stories, gaining hope from other people that had found matches [on DNA testing sites], being able to understand how all the DNA stuff works, trying to get my head around the different laws and legislations in different countries, and how there are people that are trying to change those things and make amendments to different things, I didn't know any of that was going on in the world."

Jennifer explained that although she knew very little about how donor conception and gamete donation were regulated, she felt she had "been accepted and been included into these things and into these groups and been a part of what's going on". In the meantime, she had already met up offline with a donor-conceived person whom she had met online and who lived only a few minutes away from her. With some others she had planned a meeting that would last several days, which was to take place a few weeks later in another Australian city. A person from a European country would also fly in for the occasion. The gathering was to be an opportunity to share personal experiences, and Jennifer hoped that it would help her understand "what's going on a little bit more".

Although she had only recently started to connect with others, her way of expressing herself was surprisingly similar to the rhetoric of my British interlocutors who had been involved in networking and lobbying for many years. As I mentioned in the last chapter (section 3.4), Jennifer referred to the "lessons learnt from adoption" when arguing for the right to know of the donor-conceived, which was a common argument among long-time activists. Jennifer also mentioned that "donor conception goes against a number of the UN Convention of Human Rights", and that she could not understand why it was not yet banned. In contrast to others who primarily criticised anonymity and secrecy, it was clear that Jennifer was critical of 
gamete donation per se, believing that it took away half of a child's family. However, like those of my interviewees who did not reject all forms of gamete donation, Jennifer also had an explicit problem with the way donations had been regulated in the past. When we talked about the retrospective removal of anonymity in Victoria (section 3.5), she stressed that she was in favour of the amendment and thought it should be worldwide, as the donor-conceived had "the right to know who they are and who their family is". Her idea of who belonged to the family of a donor-conceived person was very similar to what those who had been involved in activism for a long time imagined a "real" family to be like. Membership in the various groups had had an impact on her views and actions. Ever since she had come into contact with others who also rejected gamete donation, she had started to "express my feelings because I know that they are validated, and I know that they are real". Jennifer was thus able to interpret her views as something that was normal, rather than seeing herself as an extreme case. She could now formulate and justify her rejection in a way that legitimised her view, as she could present it as being in line with human rights law. Besides, she had gotten more information on DNA testing and read 'success stories', giving her the means to pursue her search and remain hopeful.

Similar to Jennifer, who by now was in contact with other donor-conceived people both online and offline, others told me that they had never met anyone else who was also donor-conceived before joining online platforms. This was especially brought up by my interviewees in the UK, who may have been members of an organisation like the DCN, but had not yet attended offline meetings, or interacted with other members online. Often, they were interested in meeting other donor-conceived persons to compare their own stories with those of others and to see how common their own experiences and opinions were. Some tried to get an overview by reading testimonies published online or by watching YouTube videos of donor-conceived persons. In Germany, on the other hand, all but one of my interviewees were on the mailing list of Spenderkinder, and they thus already had access to the narratives of other donor-conceived persons. In addition, almost all of them had closer contact with individual members with whom they were talking on the phone, writing emails, or meeting up in person. They would frequently comment that "what I found so common", or "it does appear quite common" when talking about their personal experiences and comparing them to what they had heard from others and observed online. They had the biographical comparison points that Tamara Haste from the UK, who was a DCN member, was mostly lacking. Apart from her sisters, she knew no one else who was donor-conceived. Commenting on the difficulties they faced when trying to talk to their mother, she mentioned that she did not "know how usual this is in terms of other donor-conceived people". She had not attended any DCN events yet but thought about doing so in the future, commenting that she would "love to speak to someone in that situation". 
As I will explain in more detail in section 6.2, many of my interviewees talked about their experience of not being met with a lot of sympathy in their everyday offline lives and by the people close to them. They often felt that their rejection of anonymity and their interest in the donor was not understood by those who were not donor-conceived, which was often described as painful. They did not have to face this problem in online communities that were only for the donor-conceived. They could discuss their experiences without having to deal with the comments of 'uninformed' outsiders. The Internet could thus represent a kind of safe retreat space, which seemed particularly attractive to those who were critical of donor conception per se, as it provided them with a space where they could feel normal. A similar observation has been made by anthropologist Nurhak Polat in her ethnographic study of reproductive technologies and the activism of concerned groups in Turkey (2018). As part of her research, she examined online forums that are used by those considering or undergoing fertility treatment to get information, share their stories and engage with other users. Polat argues that their growing importance can be seen as a reaction to other sources of information being "confrontational, heterogeneous and fragmented" (2018: 200, author translation). For the women and men in her study, the Internet provided a safe haven where they did not have to expose themselves to the intrusive comments of others (2018: 217). The forums studied by Polat were semi-public spaces where, after registration, participants could decide for themselves how much they want to reveal about themselves (2018: 203). Polat herself could also register, follow discussions, and get in touch with users (2018: 69-71). This constitutes a crucial difference to my own research. As I will explain in more detail later, I was not able to participate in the groups myself, which apparently did not mean that my research and I were not discussed online.

The way people used the Internet to find information and connect with others was very different from what Elizabeth Chapman told me about the mid-1990s. At that time, she had learnt about the circumstances of her conception. Having Personal Computers (PCs) and access to the Internet was not yet common, and Elizabeth commented that donor conception in general was "still quite underground in a way". She could only get information about the clinic where she had been conceived and the legal situation through books from a local library and a bookstore that was located in a nearby university town. Elizabeth told me that she had immediately perceived the Internet as an opportunity to connect with others as it had gotten more common for people to have access to it. She also described how the ways and platforms of networking had changed over the years:

Elizabeth Chapman: "To begin with, there wasn't much on there about donor conception, and it was really only good for email, but then you had to know someone who had email. And not many ordinary people had home PCs, not when I first 
started. A lot of the people I did connect with would do it in their lunch hour, on their work computer. [...] I became a member of the donor conception group of Australia, they were great, they were really supportive, they were really into donor-conceived rights and people finding their families. So that was handy."

Amelie Baumann: "And you found them online?"

Elizbeth Chapman: "That was online, well, I could contact them online, but they would also send postal stuff as well. [...] A lot of stuff was still done by phone or post, but now of course everything has moved, a lot of it is on Facebook now, things are moving, so we've got lots of groups on Facebook, but it has revolutionised things, it has meant that we can discuss and chat and support one another, it's great, it's wonderful. I don't know what we'd do without the Internet, to be honest."

Elizabeth, who strongly opposed donor conception and all forms of reproductive technologies (section 4.1), described the friends she had made through her advocacy work and her involvement in online groups as "the only good thing about being donor-conceived". She, too, had met several of them offline as well. For her, having been conceived with donated gametes was something that could unite people that were of different ages and might otherwise not meet:

Elizabeth Chapman: "Doesn't matter how old you are, when you get with another donor-conceived person, and they start talking about how they feel and their search and whatever, you just have so much in common, so much empathy with each other that you bond. It's unusual, it's quite special, the friendships that we all have with one another [...] we encourage one another, and if somebody does something in the news, 'Oh wow', we're all looking at it, we talk about it, there is a lot of camaraderie in the group. And that really does depend on the Internet."

The groups she had joined had mostly been founded by donor-conceived persons themselves. The Yahoo group PCVAI (short for People Conceived Via Artificial Insemination; it was renamed into People Conceived Via Donor Insemination later on), for example, was founded in 2000 and was only open to those who were conceived with donated gametes. ${ }^{6}$ It has been described as "[o]ne of the first networks to attempt linking donor-conceived people together" (Crawshaw et al. 2015: 74) and had 290 members in October 2019. In their "Group Description", the moderators described PCVAI as "a haven for those who do not care to defend their feelings, attitudes or opinions". Their aim was for "members to feel comfortable expressing strong opinions and feelings that may be unacceptable to their parents, friends, or the general public". ${ }^{7}$ The group itself and the messages exchanged were not 
public. ${ }^{8}$ It seemed, however, that PCVAI was more or less fizzling out when I conducted my research. According to PCVAI's public message history, which showed how many messages were exchanged in a given month, the group had a total of only 19 entries in 2018 , compared to 682 in 2008 . Sometime after I had finished my empirical research, PCVAI and other Yahoo groups came to a complete end, with Yahoo announcing in mid-October 2019 that it would be winding down its groups. ${ }^{9}$ The ways in which people network online change, with the deletion of previously shared content in the case of Yahoo indicating that these changes can be imposed ones. $^{10}$

In contrast to Yahoo groups, Facebook groups for donor-conceived persons have grown rapidly in recent years. Worldwide Donor Conceived People Network for example had been established in 2013 and had 708 members in May 2021. ${ }^{11}$ We are Donor Conceived had only been established in late 2016 and had already over 2300 members less than five years later. ${ }^{12}$ Similar to PCVAI, Facebook groups tend to have certain screening mechanisms in place to ensure that only donor-conceived persons join. Those who wish to join We are Donor Conceived are required to confirm that they are donor-conceived, and state where and when they were conceived. They are also asked to describe how they feel about the circumstances of their conception. Telling a story can thus serve as a means to claim membership to the community of the donor-conceived. Since I do not meet these criteria, had no story to tell, and did not want to deceive people, I was not able to join these groups.

Some Facebook groups not only serve as discussion and support spaces but also have an integrated register function that can facilitate matching between members (Crawshaw et al. 2015: 75). For example, a closed group called DONOR CONCEIVED

Those who wished to join PCVAI were asked to provide the moderators with some personal information and details about the circumstances of their conception. Crawshaw et al. argue that these introductory texts were "facilitating 'matching' between those conceived at the same clinic using a donor with the same donor code" (2015: 77).

From the end of October 2019, it was no longer possible to post in the groups, and from midDecember, all content was removed. Until the end of January 2020 , requests for data to be downloaded could be made.

A similar observation has been made by Kim TallBear (2013), who had joined a genetic genealogy mailing list as part of her research on genetic ancestry testing in 2005 (see section 8.1). TallBear points out that its activity "has declined considerably" (2013:109) since then. She argues that this is probably linked to "shifts in how people do their online social networking" (2013: 109-110). TallBear then cites genetic genealogist Blaine Bettinger who mentioned to her in an email that "social media platforms such as Twitter, Facebook, and blogs have substantially replaced mailing lists as a means of querying and interacting with other genetic genealogists" (2013: 110). 
OFFSPRING, SIBLINGS, PARENTS - (sperm, egg, embryo), established in 2007, encourages those who wish to join to enter their data in a "Donor Offspring Registry" document. ${ }^{13}$ This creates an unofficial register that can compensate for the absence of a formal infrastructure or enable members to circumvent official limitations. Although being donor-conceived is not a prerequisite for membership, this group also seems to be anxious to keep 'outsiders' away: after trying to join the group in April 2019, when it had more than 6700 members, its moderators seemed to have blocked me. I could no longer find the group when subsequently being logged into my Facebook account. I had mentioned in my request to join that I was doing research on donor conception, and that I was keen to learn more about the way people used online networks to connect with others. A Google search revealed that the group still existed and had over 13,000 members in May 2021. Apart from Facebook, which was mainly used by my interviewees in the UK, and the internal mailing list of Spenderkinder in Germany, hardly any other online networks were mentioned in interviews, with the exception of the website and register Donor Children. ${ }^{14}$ However, none of my interviewees mentioned that they actively used this site to network with others or find donor siblings.

The Facebook groups that I was able to find were private and closed, with messages only being visible to members. These groups can be searched and found both within the platform and through search engines. In contrast, there were other groups that I would never have heard of if my interviewees had not mentioned them to me: unlike regular closed groups, secret groups cannot be searched for or seen by non-members. Facebook users can only be added if those who are already in a secret group invite them, and only those who are in the group can see who else has already joined. As in regular closed groups, all posts and comments are visible only to those who are members. I first became aware of the existence of such groups when learning about the DCR's secret Facebook group. DCR registrants could join by sending their contact information to a specific email address and were then sent an invitation to join the group. According to Elizabeth, most Facebook groups created specifically for and by donor-conceived persons were in fact secret: donor-conceived people would first join one of the regular closed ones

13 www.facebook.com/groups/DonorConceived/ (last accessed May 28, 2021).

14 Donor Children was founded in 2013 by an American donor-conceived person (www.donorchildren.com, last accessed March 17, 2020). In addition to the exchange of information in groups and forums, the site also enables matching between its members. They can add information such as their donor code to their profile and search the site for other users that match their information. Similar to Facebook, members can make friends with other users and exchange messages. When I contacted the creator of the site, I was invited to join and post about my project in a forum. Information about my research was also shared with members through a newsletter that is sent out at irregular intervals. However, none of my interviewees reported that this was how they became aware of my project. 
and then be invited to become members of a secret group if someone who was already a member invited them. As people sometimes had to put up with what they perceived to be unsympathetic comments of others when joining 'mixed groups' that had donors and parents as members as well, closed and notably secret Facebook groups were described as safe spaces and as communities of "people who got it".

The way in which not only Facebook but also other platforms and companies handle user data often raises privacy concern. Given this background, it may seem somewhat surprising that they were seen as safe spaces. ${ }^{15}$ Similar to the way in which DNA databases were rarely criticised for their handling of data (section 8.3), no one expressed any concerns about the platform's way of dealing with personal information. The concerns my interviewees had were more about their Facebook friends potentially being able to see their membership in a group and find out about the circumstances of their conception. For this reason, they either preferred secret groups or stayed away from networking on Facebook altogether. While the opportunity to express a critical opinion seemed to attract especially those who were critical of donor conception per se to secret and closed groups, this was also something that could deter others. Jessica Robertson, for example, told me that she had joined a Yahoo group a few years ago. However, she mentioned that "the people who were vocal on there were the people who were really quite bitter about it. And who felt that we shouldn't exist, and that it wasn't natural, it shouldn't have happened." Since she felt that it would not be healthy for her "to wallow in that kind of thing", she had never become an active member and had soon stopped reading the posts. In contrast, she was more actively involved in the DCR's Facebook group and had joined the DCN as well.

Due to the closed and secret nature of these groups, it was not possible for me to follow what was happening and being discussed in them. As noted earlier, I was sometimes even blocked when contacting the administrators. The groups I had been able to join did not require an introductory text and seemed to mainly consist of parents who were trying to connect with other families that had used the same donor. A typical post would contain some basic information about the donor and the donor-conceived child: "[name of sperm bank] donor [code and/or pseudonym]. Have a girl born in 2015. Looking for half-siblings." Since I was not part of the more activist groups myself, it was a particularly strange feeling to learn that without me being aware of it, and without me having the opportunity to comment, people were talking about my work. I knew that members of the DCR's secret Facebook group had been informed about my research through a post. However, to

15 It has been argued that "concerns about privacy protection [...] are far from paranoid fantasies" (Loshin 2013: 1), as it was revealed in 2013 that an American intelligence agency had in the past been working with Facebook and other companies "to collect and store data" (ibid.). 
my surprise, Elizabeth mentioned at our first meeting that I had been "discussed yesterday" in a different group as well. Someone from Australia, whose name I knew through media reports, but with whom I was not in contact, had "put a big piece on there saying, "Amelie is looking for people". Even though this person had apparently written favourably about my work, it was still an uneasy feeling not to be able to follow the discussion. It was both fascinating and irritating to hear about the extent to which information about my work had been circulated without me being able to control or witness it.

While people would otherwise make claims for more transparency, they, too, created hidden spaces that are shielded from the outside world - on a platform that usually enables (or requests) users to publicly post information that would otherwise remain private. A strong lobby for openness in donor conception and "the transparency demanded by the Internet generally and social media specifically" (Edwards 2018: 164) have in common that they "both push what was, and could still be, private into the public domain" (ibid.). At the same time, especially the secret nature of invitation-only groups draws a line between those who are involved and those who are 'merely' donor-conceived, possibly without those on the 'outside' being aware of it. Commenting on the use of secret Facebook groups during student protests in the UK, sociologist Alexander Hensby notes that for the students who are not part of these hidden spaces, "the secret group represented a boundary between themselves and core activists" (2017: 475). The 'outside' students he interviewed were in fact aware of the secret group's existence. Hensby argues that "it is significant how Facebook - depicted as a driver of networked openness and 'connective action' by many scholars - came to play such a key role in drawing hierarchical boundaries and maintaining network secrecy" (ibid.). Given the constant insistence on openness and transparency that otherwise permeated my research, I found the closed and sometimes secret nature of these online networks surprising. However, it also seemed to be in line with the merging of authority and authenticity: if those who lack the experience of being donor-conceived are seen as having less authority, then excluding them from discussions can seem appropriate or even necessary. Besides, some experiences - particularly of those who have 'strong' opinions - might be seen as being more authentic than others, necessitating the creation of an 'insider group' among those who are already on the inside of donor conception.

\subsection{Conceiving Spenderkinder: Donor-conceived activism in Germany}

In contrast to Jennifer Bunton, who had joined as many groups as she could find (section 4.3), many of my German interviewees told me that they had ended up very quickly on the website of Spenderkinder, which was usually their most important 
source of information. It was through the site and the internal mailing list that they first learnt that DNA testing was a way to find relatives. This was the case for Diana Kraft who enthusiastically told me, "You turn on the Internet or you go online and find this association and you have all the information you need to get started gathered together." It turned out that not everyone I interviewed in Germany was also a member of Spenderkinder. Some were just on the mailing list without officially being part of the association, while others were members, attended the annual meeting and got involved in the board. The level of engagement did not necessarily have to do with how long the person in question had been a member, and some of those who were particularly active had only joined a few months before I interviewed them. Although there were differences in terms of identification with Spenderkinder and in terms of involvement, the association was nevertheless of central importance for my research: on the one hand, because it brings together (virtually) donor-conceived people, and thus was a logical contact point for me in my search for persons I could interview; on the other hand, because the association plays a central role in the transformation of anonymity in gamete donation and constitutes a particularly interesting example of donor-conceived activism.

Journalists that write about members of Spenderkinder seem to be concerned with 'giving voice' to the donor-conceived and adhere to "conceptions of voice that invoke claims of authenticity" (Cairns 2009: 328). ${ }^{16} \mathrm{I}$ do however take a different approach in this section, as I am interested in how Spenderkinder constitutes itself as a powerful voice in the public arena. I will also examine how the association itself deals with anonymity and identifiability, and how their terminology and certain official positions relate to the link between permanence and biology that was frequently evoked by activists in the UK. I will then discuss a conflict between Spenderkinder and another association, which in part also revolves around the appropriate choice of words. In the last part of this section, I will discuss the media presence of Spenderkinder, and of donor-conceived persons in general, focussing on a newspaper article that appeared in 2019.

The situation of those who could simply "turn on the Internet" and find information was not only different from the experience of Elizabeth Chapman, who began her search in the 1990s (section 4.3). Jasmin Hellermann, who was conceived

16 This seems to be the case for the first portrait of a donor-conceived persons that appeared in the weekly Die Zeit (Sußebach 2010). The donor-conceived protagonist is introduced as a member of Spenderkinder, which had been founded the year before the article was published. The author argues that the protagonist "Sonja" (a pseudonym) and her parents "are in the middle of a debate that always revolves around the same question: How far does one go for a child?" (Sußebach 2010, author translation) 'Civing voice' to the donor-conceived seems to be both a journalistic and an ethical project for him, as the following excerpt suggests: "Stories like Sonja's remain untold because the participants fall silent at the moment of conception." (Ibid., author translation) 
in Germany in the 1980s, began her search for her donor and donor siblings in the 2000s, when she had already begun her studies. Having access to PCs and the Internet was already more widespread, especially for her generation, than it had been a decade ago. However, her story indicates that it is not only the availability of a particular technology that determines how it is used. Jasmin had already been told about the circumstances of her conception at the age of ten. Although she was immediately interested in the donor and donor siblings, Jasmin had waited for some time to initiate the search process, as she wanted to control it herself without being dependent on her parents. Her plan had been to first contact the clinic where she had been conceived. Looking back on the start of her search made her laugh, as her approach was quite different from what had become common practice in recent years:

Amelie Baumann: "Did you have repeated conversations with your parents about this over the years [after she had been told that she was donor-conceived]?" Jasmin Hellermann: "Yes, of course. Well, I didn't protocol it, but of course right at the beginning the topic probably came up more often. I would guess that later on it sometimes wasn't talked about for a year or also two years because for me it was clear, ok, I won't pursue it until later anyway. And even at the beginning of my studies it wasn't that urgent, it was also more difficult because I didn't have a reference point [Anknüpfungspunkt], so for me it was somehow clear, ok, I have to start in the clinic to generate information, because how else am I supposed to find others who have been conceived the same way. And with the Internet back then it just wasn't as [laughs] today, you can't really imagine that anymore, you would google it first, but I didn't come up with that idea back then. And this term "Spenderkinder" was also not yet really established so that you could have googled it."

Although PCs and the Internet had already been available to her in the mid-2000s, it had not occurred to her to turn to Google in particular, which for many of my interviewees seemed to have become a kind of automatic reaction to questions and concerns of any kind. DNA databases like FTDNA had not existed at that time either. Sometime after starting her studies, Jasmin eventually contacted the clinic where she had been conceived and met the doctor who had treated her mother. $\mathrm{He}$ did not give her any information about her donor but told her about DI Kind ("DI child"), the website created in 2006 by another donor-conceived person, when she asked him if others had contacted him before. The physician had made a contribution, albeit unintentionally, to the later founding of the association Spenderkinder, as Jasmin contacted the person behind DI Kind. She told me that in 2009, when the group around DI Kind had grown to about 15 people living in Germany, Switzerland and Austria, they decided to take the next step: "Then we said, 'And now we are founding an association, so that we can speak a little bit more in public of an as- 
sociation opinion [Vereinsmeinung], and so that we're not always perceived as being isolated from each other."

Since Spenderkinder officially argues that anonymous donations have never been legal in Germany, one of their first goals was to enforce the current legal situation - instead of changing it. In addition, they advocated the creation of a register early on to ensure the permanent storage of donor information. Especially the government consultations they participate in show that Spenderkinder is now considered an authority on anonymity in gamete donation and reproductive technologies. For example, they were invited to a hearing on the German donor register and also when a draft law on the cost absorption for fertility treatment was being discussed. They are now being asked about topics that are not exclusively related to sperm donation and anonymity. When watching online streams of these public hearings, it was striking that their representatives often received many questions compared to other experts present. I would argue that the legal training of one of the persons who was particularly active in the public sphere and often represented Spenderkinder on such occasions helped them to establish themselves in the political arena. This opinion was also shared by others outside the association: despite being critical of their influence, they spoke with respect and admiration about her commitment and legal expertise.

Before the association was founded in 2009 , there had already been a mailing list for donor-conceived persons under the name "Spenderkinder". According to my interviewees, those who join the list are asked to introduce themselves in an introduction email, with information on where they were conceived and how they had learnt about the circumstances of their conception. Similar to Facebook groups, having a story of one's own functions as an entry ticket. However, these texts do not appear to be uniform in terms of content and length: while Melanie Weber told me that she had kept her text very short, David Winkler had written a long and detailed text which he had sent me before the interview. Melanie had also mentioned that the person she first contacted had told her that she did not have to use her real name. While none of the people I interviewed stated that they used a pseudonym on the list, this possibility seemed to exist.

According to the website, Spenderkinder had over 200 members in February 2021 and a managing committee that is elected annually. The association does however not belong to the group of 'registered associations', which, in Germany, have the affix "e.V"-"Eingetragener Verein" attached to their name. I was told by a member of the board that this was only a question of costs, since registration and any changes, for example a new board member, must be paid for. Critics of the association argued that due to the missing registration, it was not possible to verify information that Spenderkinder posts on its website by requesting information from the register of associations (Vereinsregister). Such a request can be made by anyone to find out the names of the board of directors, for example. At the time 
of my research, the association and its activists in particular did indeed have a rather complex and seemingly contradictory way of handling their own anonymity and identifiability. Some members appeared in public with their full names, for example when appearing as experts at government consultations. Nevertheless, at the time of my research the website itself did not show pictures of members or of the board. ${ }^{17}$ Surnames were usually only mentioned in press releases. The first names used in blog posts often seemed to be abbreviations. Those who appeared in public with their names did not seem to be afraid that the circumstances of their conception would become publicly known. Nevertheless, it is noticeable that on the website itself the members were to a certain extent indistinguishable from each other, even though the section "Opinions and Stories" did highlight individual members with stories that focused on how they found out and felt about the anonymous nature of their conception. ${ }^{18}$

In the mid-200os, Jasmin had not yet had the idea to google "Spenderkind". This points to a particularly interesting aspect of donor-conceived activism in Germany, namely the development and establishment of the term "Spenderkind". When I started working on my dissertation at the end of 2015, it had already become a widespread term and was used in Germany not only for the members of the organisation Spenderkinder but also for all donor-conceived persons. ${ }^{19}$ However, my brief enquiry into media representations of reproductive technologies published since the 1970s suggests that the term and the way of referring to donor-conceived persons has undergone some changes. Some of the first articles on sperm donation that were published in the weekly Die Zeit in the 1970s use the word "Kunstkinder" when referring to children conceived with donor sperm (Löbsack 1972, 1973). The author's critical stance towards technologically assisted reproduction suggests that the term was chosen to emphasise the unnaturalness and artificiality (Künstlichkeit) of children conceived with donated gametes. ${ }^{20}$ When the term Spenderkind first appeared in Die Zeit three decades later (Spiewak 2004), it was not yet used to describe

17 A banner announcing their social media campaign (introductory chapter) was added to the website when the campaign was launched. It shows the faces of two members, both of whom had already appeared in the media.

18 www.spenderkinder.de/ueberuns/meinungenundgeschichten/(last accessed April 10, 2020).

19 Often people were irritated when I used the term "donogen gezeugte Person" and not the term "Spenderkind" when speaking or writing about my work in German, even though I explained that I avoided the term in order to avoid confusion with the association of the same name.

20 According to Theo Löbsack, doctors seem to have no reservations about "wrestling from nature at any price what it has decided to withhold in individual cases, perhaps not without good reason" (1972, author translation). He was firmly against DI, which he described as the "instrumental insertion of sperm from an extramarital third party into the sex organs of women" (1973, author translation). 
donor-conceived persons (see also Spiewak 2007; Bahnsen and Spiewak 2008). Instead, it was used to describe those who today are often referred to as the "saviour siblings" that are suitable as an organ or cell donor for an ill sibling. They are conceived through IVF or Intracytoplasmic Sperm Injection (ICSI) ${ }^{21}$ and PGD. ${ }^{22}$ It was not until 2008 that Spenderkind appeared as a (or rather the) term for donorconceived persons (Spiewak 2008).

Figure 2: „Samenspende“- das Kind mit seinen genetischen und sozialen Elternteilen ("Sperm donation" - the child with its genetic and social parents)

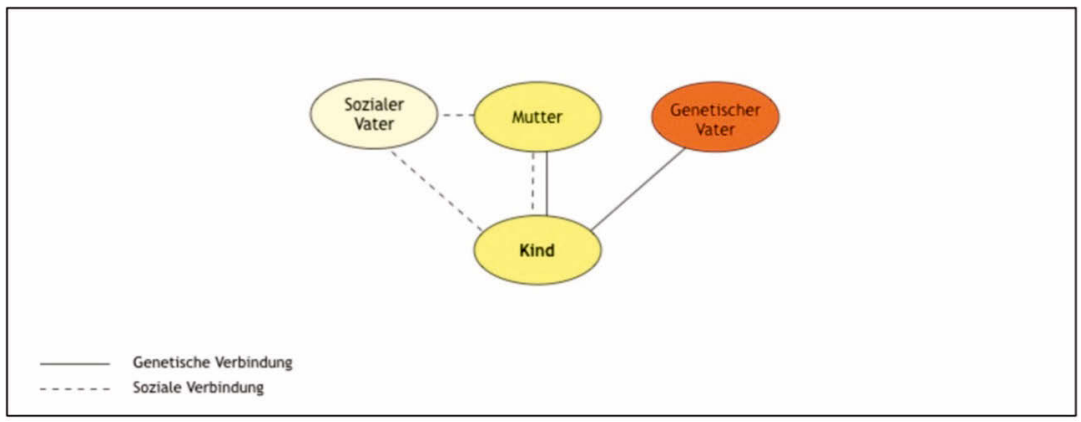

Source: www.spenderkinder.de/infos/psychologisches

Jasmin, who had been with the association from the beginning, told me that when Spenderkinder was founded, the first members had thought carefully about what they should call themselves. The English term "donor offspring" did not seem to have a perfect translation, and "Spenderkinder" was the most accurate one they could find. ${ }^{23}$ They had chosen this name because they felt it best expressed the relationship between the donor and the person conceived with his sperm. This person would eventually grow up and no longer be a child in terms of age but would always remain a child in relation to the donor with whose sperm it had been conceived.

21 ICSI is an IVF procedure. It involves the injection of a single sperm cell directly into the egg.

22 Only an embryo that has a high genetic compatibility with the sibling that is to be 'saved' is implanted. PGD was only allowed for life-threatening diseases in 2011. The creation of "saviour siblings", which are now commonly referred to as "Retter-Ceschwister" in Cerman, continues to be illegal.

23 Jasmin Hellermann also mentioned that similar terms and groups had emerged in other countries when Spenderkinder was founded; for example, the Dutch organisation Stichting Donorkind was founded in 2007 (www.donorkind.nl, last accessed May 28, 2020), with "donorkind" corresponding to the German "Spenderkind". The term "donorkind" is used in academic publications written in Dutch (such as Pennings 2016; Schrijvers et al. 2018), suggesting that the Dutch term might not be as contentious as the German one. 
The permanent and special nature of the connection between donor and donorconceived person is also highlighted on the association's website. Here, among other things, information is provided on the "psychological aspects" of treatment with donor sperm. ${ }^{24}$ According to the site, when a family is 'started' with donated sperm, three people are involved, and the term "founding a family in threes/with three people" - "Familiengründung zu dritt" is introduced. The "family systemic" (familiensystemische) situation and position of donor-conceived persons is then explained in various diagrams (see for example figure 2). Connections are represented by lines between ovals representing the child, parents and the donor. While the connections between a child and his/her mother and the child and his/her "genetic father" are shown with solid lines, the connection between the child and his/her "social father" is represented with a dashed line. The donor is described as having "a guaranteed, inextricable genetic link with the child, without any obligations attached". The position of the "social father", however, is described as "the weakest in the family system" since he "cannot be sure of his relationship with the child [...] because there is no genetic connection" (author translations). These schematic representations fit with the "familiar kinship pattern of bilateral descent, through which the offspring inherits an equal amount of shared substance from both parents" (Franklin 2013: 254). While the work of Weston (1991) questions, in the words of Carsten, "the takenfor-granted link between permanence and biology" (2000b: 695), the permanence of connections is again presented as something rooted in the biological nature of relationships. As Strathern points out, "for Euro-Americans there is no getting around the tie that exists with those persons whose genetic substances combined at the child's conception" (1999a: 22) - regardless of whether a relationship is activated or not. This characteristic of Euro-American kinship is, I suggest, epitomised in the terms that Spenderkinder uses. Strathern argues elsewhere that anonymous donors are involved in the procreation of a child, but not in his/her reproduction, which "bring[s] into existence something that already exists in another form" (1995: 354). Donors as "new [procreative] actors associated with reproductive medicine create a field of relationships that does not overlap in any simple way with familial ones" (1995: 351). They can thus be said to "disperse kinship". At the same time, the way in which Spenderkinder makes sense of the connection between the donorconceived person and the donor illustrates that "ideas are always enunciated in an environment of other ideas" (Strathern 1992: 10). Both among German donor-conceived activists and internationally, there seems to be a longing for an older model in which reproduction and procreation are not separated. While "there is more to kinship than family life" (Strathern 1995: 351), ideas about dispersed kinship are formed and explored, as is the case for any ideas, "in contexts already occupied by 
other thoughts and images" (Strathern 1992: 10), namely by ideas about (nuclear) family life.

Finding the right terminology also seemed to play a role in a conflict that existed between Spenderkinder and another organisation at the time of my research: ${ }^{25}$ DI-Netz was founded in 2013 , is a registered association, and sees itself as an association of families created through sperm donation, rather than merely as an association of parents (as it was usually referred to by the donor-conceived persons I interviewed). Together with a group of other couples who had chosen to be open with their children, Claudia Brügge and her husband had founded DI-Netz in 2013. The association has become politically influential over just a few years and got invited to some of the same consultations as the donor-conceived group. DI-Netz also offers seminars for people considering treatment with donor sperm, as well as seminars that deal with the topic of disclosure. On the DI-Netz website it is noticeable that the term "Spenderkinder" is only used in relation to the association of the same name, but not in relation to the children within the association or donorconceived persons in general. ${ }^{26}$ Brügge, who was on the board of directors at the time of the interview that took place in 2017, explained that she did not refer to the children of the member families as "Spenderkinder". While she advocated early disclosure and emphasised that she was open to talking about the donor, she did not use the term, as she felt that it was too narrowing. According to a blog post, the association would like the term "Spenderkinder" to no longer be used on the website of the German sperm donor register, arguing that many of their member families "do not feel understood when this term is used" (fühlt sich mit diesem Begriff nicht verstanden) (DI-Netz 2019, own translation). At the time of writing (May 2021), however, the term was still used on the register's website, ${ }^{27}$ although it is not mentioned in the Sperm Donor Register Act. ${ }^{28}$

25 The controversy surrounding the term is reflected in the debate surrounding a book entitled Spenderkinder, which was published in 2016 (Oelsner and Lehmkuhl 2016). The authors, a psychotherapist and psychologist, interviewed ten persons who are members of Spenderkinder; in the book, the term is however also used for donor-conceived persons in general. In its main part, their stories are condensed into "life sketches" (Lebensskizzen). In its cover text the book is described as follows: "They [the authors] present the authentic voices of today's adult children and explain why knowledge about one's own origins is so important for the development of identity." (Author translation) While the book received a very positive review on Spenderkinder's website (Spenderkinder 2016c), it was met with a lot of criticism elsewhere (see for example Brügge 2017) and was described as unscientific and one-sided.

26 The DI-Netz website sometimes uses the term "children after sperm donation" (Kinder nach Samenspende).

27 www.dimdi.de/dynamic/de/weitere-fachdienste/samenspender-register/ (last accessed May 28, 2021).

28 The Sperm Donor Register Act speaks of "people conceived through heterologous insemination in medically assisted artificial fertilisation" (Personen, die durch heterologe Verwendung 
The conflict between the two organisations became particularly clear in a conversation with a member of Spenderkinder whom I told that I had attended an event where I had been able to make some interesting contacts with various organisations. My interviewee then commented with a disdainful tone that I probably had met someone from DI-Netz as well. In view of the central claims of DI-Netz, which at first glance appear similar to what Spenderkinder was and is fighting for, this conflict might initially seem surprising. Although the founding members of DINetz had the much larger DCN as their model, the German organisation is more explicit in its rejection of anonymity than its British counterpart. ${ }^{29}$ DI-Netz advocates for early disclosure and openness in families, which are also central claims of Spenderkinder, and had early on lobbied for the creation of a central register. However, some of Spenderkinder's more activist members were mainly of the opinion that DI-Netz did not recognise, or played down, the challenges that donor conception could pose to a child and to families in general, which are depicted in the "family systemic" diagrams. Other members of Spenderkinder were less critical and interpreted the existence of the association as an indication that parents are now more aware of the importance of openness.

In contrast to families of DI-Netz, members of Spenderkinder are often portrayed in German magazines, newspaper articles, podcasts and documentaries. In media reports about donor-conceived persons, it is in fact mostly members of Spenderkinder who are portrayed. ${ }^{30}$ Of the ten persons that I interviewed who were members and/or were on the mailing list, seven have been in the print media, on radio or on TV. To what extent this ratio is representative is unclear. It seems likely that someone who wants to convey a message to the public is also more inclined to talk to a researcher. However, the large number of people whose stories are now circulating online and in print, and of whom I do not all recognise, suggests that the people I met are not the only members who are talking to journalists. Being active in the media does not seem to be a marginal phenomenon.

von Samen bei einer ärztlich unterstützten künstlichen Befruchtung gezeugt worden sind) (SaRegC $2017 \S 1(2))$.

29 DI-Netz is explicitly against anonymous donations and has, for example, issued posters and postcards with short messages that convey the organisation's main principles; the child's right to know being one of them. In contrast, the DCN's position is more ambivalent, although the organisation supported the change in the law that came into force in 2005 . The DCN points out on its website that parents who would like to secure access to information for their children might feel forced to go abroad for treatment because of financial or time pressure, and as a result have to accept anonymous donations. The DCN therefore aims to "support parents in making decisions they can feel confident about, with a clear view of the long-term implications for the whole family" (DCN, n.d.).

30 This is the case for all three major articles that appeared in the weekly Die Zeit between 2010-2019 and focused on donor-conceived persons (Sußebach 2010, 2019; Becker 2014). 
Although David Winkler and Diana Kraft's experiences (section 4.2) were in some ways unlike other stories I had been told, their decision to make their stories public was in itself not unusual. This also appears to be the case on an international level: half of my interviewees have in the meantime already spoken to a journalist at least once. There clearly seems to be a market for their narratives. The question arises as to why stories about donor-conceived persons have become so popular. While I will not go into detail about the content of the articles and documentaries for which donor-conceived persons were interviewed, as such an analysis would go beyond the scope of this book, ${ }^{31}$ I briefly want to argue that their growth seems to tie in with a general trend towards representing topics pertaining to reproductive technologies via personalised reportages.

In her analysis of how the public image of sperm donors and reporting on reproductive technologies has developed over time, Kristina Schneider (2010) found that from the 1990s onwards, personalised histories were increasingly published, the protagonists of which were mostly childless women and couples. This trend continued in the 2000 s, with the 'fate' of the donor-conceived now also being taken up by the media: the first portrait of a donor-conceived person that appeared in the weekly Die Zeit, for example, was published in 2010 (Sußebach 2010), ${ }^{32}$ whereas sperm donors continued to be mostly absent in the media (Schneider 2010: 68-69). Commenting on what she describes as "I can't have a baby" stories, which are circulated by British, Canadian and US media, Maureen McNeil argues that narratives depicting the suffering of childless women and couples "have become classic tales of the late twentieth- and early twenty-first-century Western life" (2007: 103). McNeil suggests that apart from "the growth in testimonial cultures" (2007: 105) and "revelation media programmes" (ibid.), "the concerted excavation and generation of difficulties around human reproduction" (2007: 106) has been a crucial factor for the immense proliferation of stories about infertility. I suggest that the ongoing "elaboration of the ways in which reproduction can go wrong" (ibid.) has also contributed to the growing media presence of the donor-conceived. Similar to personal stories about infertility being used as "lead-ins for expositions about developments in reproductive technoscience for popular readerships and audiences"

31 But see earlier this section for a brief insight into how the donor-conceived are represented, or referred to, in the weekly Die Zeit.

32 A donor-conceived adult was first interviewed, together with his parents, in 2000 (Grefe et al. 2000). The introduction of the article contains the names of the interviewed persons (who are also listed as co-authors), and the article does not state that they were pseudonymised. Its content differs significantly from what was published later (see Sußebach 2010, 2019; Becker 2014), as the donor-conceived person, who was told about the circumstances of his conception at the age of seven, emphasises that he has no interest in the donor. The word "Spenderkinder" is not yet used. 
(ibid.), stories about donor-conceived persons have become another means of "human-interest framing" (ibid.). Interviews with donor-conceived persons are often part of TV documentaries that deal with reproductive medicine, as was also the case with the documentary Diana had been interviewed for (section 4.2).

McNeil argues that "I can't have a baby" stories embody "a classic and simple form of salvation narrative" (2007: 103), with those struggling with infertility moving away from suffering and towards change. A similar narrative line characterises the 2019 Die Zeit article (Sußebach 2019), in which the protagonist, who had managed to identify her donor with genetic testing, speaks of "healing" (Heilung) after having moved from not-knowing to knowing. The multi-page article, which was entitled "Deep in the Genes" (Tief in den Genen), tells the story of one of the founders of Spenderkinder who is depicted on a large-format, colour photograph. ${ }^{33}$ The article's contents speak to the far-reaching consequences of DNA testing in terms of anonymity, which will be discussed in detail in chapter 8: after years of being registered with a commercial genetic testing site, the protagonist had joined another site in the hope of finding her anonymous donor. She was immediately matched with a close genetic relative whose name she did not recognise. A subsequent Google search led her to an obituary that this person had published. It listed someone from Germany as one of the relatives of the deceased person. The protagonist recognised his name as the name of the doctor who had treated her mother, and who was also one of the pioneers of DI in Germany. He had used his own sperm for the insemination, without telling his patient. ${ }^{34}$

The way the protagonist's search for her donor is described is also reminiscent of the journey narrative, with the donor-conceived person overcoming numerous obstacles in the process of searching, such as the doctor choosing not to reveal any information about his donors. Several of my British interviewees spoke of their "journey" with donor conception (see for example Jade Foster in section 6.3). ${ }^{35} \mathrm{An}$ thropologist Gay Becker describes the metaphor of life as a journey as "a central motif in Western societies" (2000: 31; see also Mattingly 2010: 72). It is an organising metaphor that can help to (re)create a sense of continuity (Becker 1997: 7), as a

33 The article was published in the "Dossier" section of Die Zeit, which is characterised by particularly long articles that often focus on the story of a specific person.

34 In addition, the physician had bought a test from yet another testing site, which the protagonist had also joined. Apparently, he had been interested in the personalised health reports that the company offers and had forgotten to log off from the "matching" function. He was therefore matched with the donor-conceived protagonist.

35 None of my Cerman interviewees spoke of their "Reise", which would be the direct translation of "journey". However, they too used words that conveyed a sense of transformation. Several people spoke of their "Auseinandersetzung" with their origins (see for example David Winkler in section 8.4). This term can range in meaning from "dispute" to "analysis" and was mostly used to describe an active and critical $\mathrm{n}$ with donor conception. 
potential disruption can be reinterpreted as being part of a transformation. Apart from the recourse to a classical narrative form, the story also becomes resilient because, similar to the stories studied by McNeil (2007: 103), questions of context are not reflected upon despite the highly personal nature of the article. The protagonist's need to know is not discussed in relation to the prevailing understanding of kinship, within which such a need makes sense in the first place. Instead, genes are merely presented as "a sought-after narrator" (Sußebach 2019, author translation).

The author also argues that "the case is of exemplary relevance, of public interest [...] because it shows what can happen when progress is beyond the control of society and legislation. When a blind spot opens up in which pioneers whether nuclear physicists, bacteriologists or reproductive physicians - remain unobserved. And act." (Sußebach 2019, author translation) ${ }^{36}$ Fears that reproduction and technology might 'go awry' are analysed by Susan Erikson (2003) in her ethnographic study of prenatal diagnostic technologies in two German hospitals. Both ultrasound and amniocentesis may result in the detection of foetal anomalies, with some women choosing to terminate a pregnancy. Erikson argues that the Nazi era, with its history of eugenic politics and medical abuse, has left its imprint on policies and public discourses where "a history of "society gone wrong" provides an inescapable backdrop to contemporary praxis" (2003: 1988). Post-diagnostic abortion therefore not only raises the question "whether such abortions are "medicine gone awry", but also about whether medicine has gone awry again" (ibid., emphasis in original). Given this background, it is not surprising that the actions of a pioneer of DI are interpreted as an example for science escaping societal and legal control. The reference to nuclear physicists as another group of potentially dangerous pioneers evokes images of nuclear explosions, and the mention of bacteriologists immediately suggests the release of invisible, yet deadly particles. Putting reproductive health professionals on an equal footing with them frames the treatments they offer as something that requires stricter control mechanisms. While the article describes a new phenomenon with its focus on DNA testing, this analysis shows that it also ties in with a common pattern of interpretation.

36 See also Brügge (2018) for a commentary on the case. Even before the article was published, the person named in the article had reported her discovery on the website of Spenderkinder under a pseudonym (Spenderkinder 2018c). In the commentary that Brügge subsequently published, she argued that the physician had violated his patient's reproductive autonomy by choosing to procreate with her without her being aware of it (Brügge 2018). 


\subsection{Recapitulation}

Although the decision to talk to journalists and to become publicly active could be motivated in different ways, for those who decided to go public, it was often about advocating a certain ideal of what family should be like. For those who were critical of donor conception per se and not only of the principles of anonymity and secrecy, it was about using their personal story to warn others of the dangers of the practice. Real families, in their eyes, were those whose members were genetically related to each other. They were convinced that anonymous gamete donation had a negative effect on the wellbeing of the donor-conceived and their ability to be intact members of society. I suggest that this kind of harsh criticism is based on the alleged connection between knowledge and "identity formation" that was also evoked by 'milder' voices. Others, who were not critical of gamete donation per se and believed in the importance of openness, wanted to promote the normalisation of the practice by putting their stories in a public space. They also wanted to increase their chances of finding donor siblings and the donor. The ideal of the open, honest family was something that was also very prevalent in the interviews with those who had not shared their stories with journalists.

Since most of the donor-conceived did not know anyone else who shared the same 'fate', and whom they could tell their stories without being misunderstood, many turned to the Internet to find others who were in the same situation. The safe spaces they found online, where they felt protected from the intrusive comments of uninformed outsiders, were described as places where they could experience and create community, understanding, encouragement and normality. The groups they joined online were mostly closed and often hidden. They create a new 'outside' and 'inside' by keeping away not only those who are not donor-conceived but also those who are not invited for other reasons. While the people I interviewed in the UK were sometimes members of several groups and usually the most active on Facebook, the association Spenderkinder was the first (and often only) contact point and source of information for the donor-conceived persons I met in Germany. The association began as a website and mailing list and has developed into a powerful but not uncontroversial player in debates about anonymity and reproductive technologies. The more 'sober' line of argumentation pursued by Spenderkinder with regard to the right to know, which also seems to have shaped the views of its members, differs from the positions of British activists. Nevertheless, the connection between permanence and biology is again part of the association's official terminology and public statements. Spenderkinder has a strong media presence, and the narratives of the donor-conceived seem to be popular among journalists on an international level as well. While articles and documentaries sometimes address new technologies, they also seem to tie in with common ways of interpreting medical and reproductive technologies. 